Article

\title{
A Potential Mechanism for the Anti-Apoptotic Property of Koumine Involving Mitochondrial Pathway in LPS-Mediated RAW 264.7 Macrophages
}

\author{
Zhi-Hang Yuan ${ }^{1,2}$, Zeng-Enni Liang ${ }^{3}$, Jing Wu ${ }^{1,2}$, Jin-E Yi ${ }^{1,2}$, Xiao-Jun Chen ${ }^{1,2}$ \\ and Zhi-Liang Sun $1,2, *$ \\ 1 Department of Clinical Veterinary Medicine, College of Veterinary Medicine, Hunan Agricultural University, \\ Changsha 410128, China; yuanzhihang84@163.com (Z.-H.Y.); wu23jing@aliyun.com (J.W.); \\ smart16@aliyun.com (J.-EY.); s51857176@gmail.com (X.-J.C.) \\ 2 Hunan Co-Innovation Center for Utilization of Botanical Functional Ingredients, Changsha 410128, China \\ 3 Department of Hunan Agricultural Product Processing Institute, Changsha 410128, China; \\ enni_007@163.com \\ * Correspondence: zhiliangsun15@163.com; Tel.: +86-731-8467-3712
}

Academic Editor: Thomas J. Schmidt

Received: 16 July 2016; Accepted: 21 September 2016; Published: 1 October 2016

\begin{abstract}
Koumine is a kind of alkaloid extracted from Gelsemium elegans (G. elegans). Benth, which has shown promise as an anti-tumor, anxiolytic, and analgesic agent. In our present study, the effect of koumine on lipopolysaccharide (LPS)-mediated RAW 264.7 cell apoptosis was evaluated. MTT assays showed that koumine obviously increased cell viability in LPS-mediated RAW 264.7 macrophages. Preincubation with koumine ameliorated LPS-medicated apoptosis by decreasing reactive oxygen species (ROS) production, which resulted in a significant decrease in the levels of nitric oxide (NO) and inducible nitric oxide synthase (iNOS). In addition, koumine-pretreated RAW 264.7 macrophages exhibited reduction of LPS-induced levels of TNF- $\alpha$, IL-1 $\beta$, and IL-6 mRNA. Furthermore, pretreatment with koumine suppressed LPS-mediated p53 activation, loss of mitochondrial membrane potential, caspase- 3 activation, decrease of Bcl-2 expression, and elevation of Bax and caspase- 3 expressions, suggesting that koumine might act directly on RAW 264.7 cells to inhibit LPS-induced apoptosis. It seems as though the mechanism that koumine possesses is the anti-apoptotic effect mediated by suppressing production of ROS, activation of p53, and mitochondrial apoptotic pathways in RAW 264 cells. Koumine could potentially serve as a protective effect against LPS-induced apoptosis.
\end{abstract}

Keywords: koumine; anti-apoptotic effect; mitochondria; caspase

\section{Introduction}

Apoptosis, an evolutionarily conserved form of cell death, is a pathophysiological and physiological process involved in various signaling pathways [1]. These pathways can be triggered by a host of cytotoxic stimulus, which induce activation of executioner caspases and other signaling cascades that ultimately lead to apoptotic cell death. A structural part of the outer membrane of Gram-negative bacteria called LPS involves in a variety of inflammatory disorders via regulation of the expression of a variety of inflammatory cytokines and cytotoxic mediators, and has been widely applied in animals as a model for anti-inflammatory evaluation [2]. Additionally, LPS triggers severe immunological reactions, resulting in cell apoptosis [3]. Currently, LPS-induced apoptosis has been studied both in vitro and in vivo. LPS was reported to efficiently mediate chondrocyte apoptosis evaluated by the increase of caspase- 3 expression and those caspase- 3 related proteins [4]. LPS stimulates apoptosis by death pathway and may utilize a novel death domain-containing protein 
to transduce a death signal in a human microvascular endothelial cell line, HMEC-1 [5]. During bacterial infection, acute lung injury is related with neutrophilic inflammation, disruption of the alveolar-capillary barrier, and cell apoptosis [6]. Cell apoptosis was also investigated in animal models with LPS administration. It was found endothelial cell apoptosis in the liver and lung of mice injected with LPS [7].

Previous investigations have shown that alkaloids extracted from Chinese medicinal plants protect against LPS-induced apoptosis. It has been proved that alkaloid-enriched extract from Dendrobium nobile Lindl. prevent against LPS-induced apoptosis in rat brain [8]. Lu et al. reported that total alkaloids from rhizome Coptis chinensis are a potent protective agent against Helicobacter pylori LPS-induced gastric mucosal inflammation, whose mechanisms may be related to its inhibitory effect on epithelial cell apoptosis [9]. Gelsemium is an Asian and North American genus of flowering plants belonging to the family Loganiaceae, which contains three commonly known species: Gelsemium elegans (G. elegans), Gelsemium sempervirens (G. sempervirens), and Gelsemium rankinii (G. rankinii). G. elegans grown in China and Southeast Asia was reported to produce toxicity in humans. So far, about 49 alkaloids were isolated from G. elegans [10]. Though these alkaloids are similar in structure, their pharmacological action are not the same. Interestingly, some alkaloids extracted from G. elegans can increase the efficiency of animal growth. For example, extended oral administration with low-dose koumine can help growth promotion in pigs. Koumine (molecular formula: $\mathrm{C}_{20} \mathrm{H}_{22} \mathrm{~N}_{2} \mathrm{O}$; molecular weight: 306.40) is the most abundant molecule among the alkaloids of G. elegans [11] and its chemical structure is shown in Figure 1 [12]. Previous studies reported that koumine has shown promise as an anti-tumor, anxiolytic, and analgesic agent [13-15]. Moreover, koumine was demonstrated to have a significant analgesic effect in rodent behavioral models of inflammatory and neuropathic pain [16].

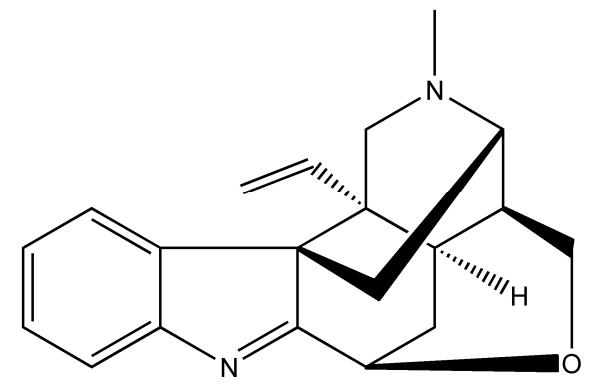

Figure 1. Chemical structure of koumine.

In the present study, we investigated the protective effect of koumine on LPS-induced apoptosis in RAW 264.7 macrophages. Here we provide evidence for the first time that koumine prevented lipopolysaccharide-induced apoptosis through regulation of mitochondrial pathway in RAW 264.7 macrophages.

\section{Results}

\subsection{Cell Viability}

MTT assay was performed to determine the suppressive effect of koumine in RAW 264.7 macrophages. As shown in Figure 2, a reduction in cell viability from $100 \%$ to $67.6 \%$ was observed after incubation with $1 \mu \mathrm{g} / \mathrm{mL}$ of LPS for $24 \mathrm{~h}(p<0.01)$. However, when it was pretreated with koumine, a marked increase in cell viability was observed in the LPS-stimulated RAW 264.7 cells. 


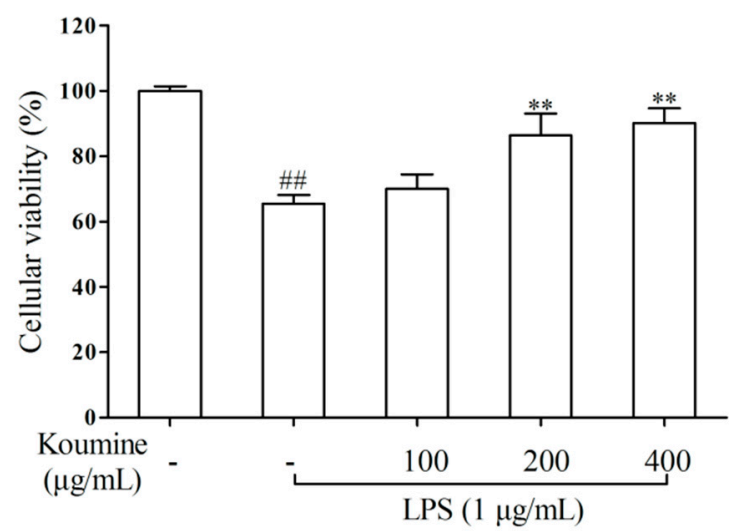

Figure 2. Protective effect of koumine on viability of RAW 264.7 macrophages measured by the MTT assay. Cells were pretreated with or without different concentrations of koumine (100, 200 and $400 \mu \mathrm{g} / \mathrm{mL}$ ) for $1 \mathrm{~h}$, and exposed to $1 \mu \mathrm{g} / \mathrm{mL}$ of LPS for $18 \mathrm{~h}$ in the mediums containing koumine. Then cell viability was determined by MTT assay. The data were expressed as mean $\pm \operatorname{SD}(n=5)$. ${ }^{\# \#} p<0.01$ vs. control group; ${ }^{* *} p<0.01$ vs. LPS group. - means non-koumine treatment.

\section{2. iNOS qRT-PCR Assay}

We investigated the effect of koumine on LPS-stimulated the levels of iNOS mRNA. As shown in Figure 3, the level of $i N O S$ mRNA was obviously reduced after the cells were cultured with LPS in the medium containing koumine, compared with LPS only group. In LPS-stimulated RAW 264.7 cells, the inhibitory effect of koumine on $i N O S$ mRNA level was showed at a concentration of $100 \mu \mathrm{g} / \mathrm{mL}$, and the maximum effect of koumine was evident with a concentration of $400 \mu \mathrm{g} / \mathrm{mL}$.

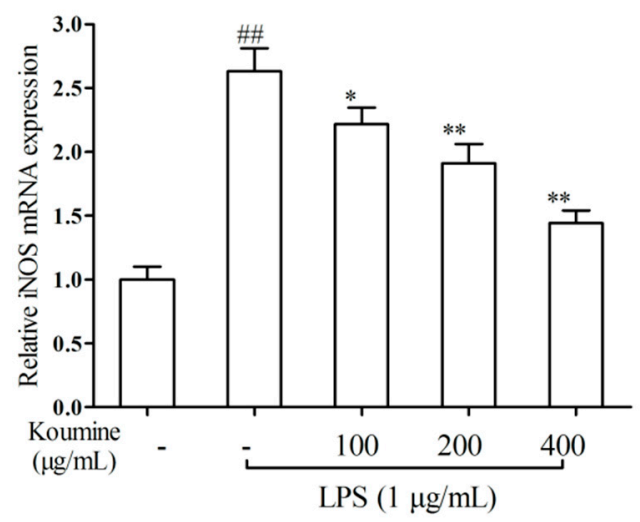

Figure 3. Suppression of the levels of iNOS by koumine in LPS-mediated RAW 264.7 macrophages. Cells were precultured with koumine $(100,200$ and $400 \mu \mathrm{g} / \mathrm{mL})$ for $1 \mathrm{~h}$, and exposed to $1 \mu \mathrm{g} / \mathrm{mL}$ of LPS for $18 \mathrm{~h}$ in the mediums containing koumine. The level of iNOS and $\beta$-actin was determined using qRT-PCR assay. The level of iNOS expression was calculated after normalizing signals against the "housekeeping" gene $\beta$-actin. The data were expressed as mean \pm SD. $(n=3)$. ${ }^{\# \#} p<0.01$ vs. control group; ${ }^{*} p<0.05$ and ${ }^{* *} p<0.01$ vs. LPS group. - means non-koumine treatment.

\subsection{ROS Assay}

To examine if the protective effects of koumine are due to a decrease of ROS production in LPS-mediated RAW 264.7 cells, the production of ROS was determined by using dichlorofluorescein-diacetate (DCFH-DA). RAW 264.7 cells treated with LPS rapidly increased intracellular ROS level, which was effectively attenuated by pretreatment with koumine in a dose-dependent manner (Figure 4). 


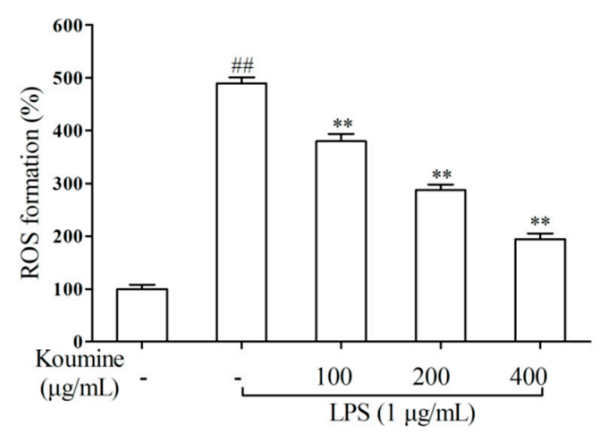

Figure 4. Koumine precultivation suppressed LPS-induced production of ROS in RAW 264.7 macrophages. Cells were precultured with koumine (100, 200 and $400 \mu \mathrm{g} / \mathrm{mL}$ ) for $1 \mathrm{~h}$, and exposed to $1 \mu \mathrm{g} / \mathrm{mL}$ of LPS for $18 \mathrm{~h}$ in the mediums containing various concentrations of koumine. The analysis of ROS levels was determined by DCFH-DA after treatment. The data were expressed as mean \pm SD. $(n=3) .{ }^{\# \#} p<0.01$ vs. control group; ${ }^{* *} p<0.01$ vs. LPS group. - means non-koumine treatment.

\subsection{TNF- $\alpha, I L-1 \beta$, and IL-6 mRNA Expression}

Quantification of inflammatory cytokine mRNAs was analyzed by quantitative real-time polymerase chain reaction (qRT-PCR) in the macrophages. An obvious promotion in the expression of TNF- $\alpha$, IL- $1 \beta$, and IL- 6 mRNAs was exhibited in macrophages treated with LPS only. Additionally, koumine concentration dependently prevents the expressions of IL-1 $\beta$ (Figure 5A), IL-6 (Figure 5B), and TNF- $\alpha$ (Figure 5C) mRNA in LPS-induced RAW 264.7 cells. The minimum inhibitory concentration was showed at a concentration of $200 \mu \mathrm{g} / \mathrm{mL}$ koumine, and the maximum inhibitory concentration was at a concentration of $400 \mu \mathrm{g} / \mathrm{mL}$ koumine.

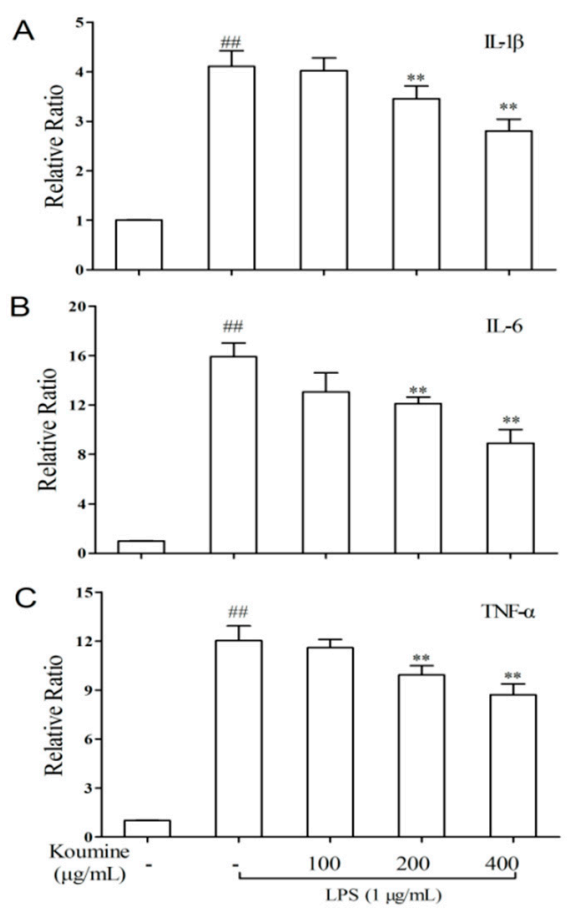

Figure 5. Koumine precultivation hampered LPS-induced expressions of inflammatory cytokine mRNAs in RAW 264.7 macrophages. Cells were precultured with koumine (100, 200 and $400 \mu \mathrm{g} / \mathrm{mL})$ for $1 \mathrm{~h}$, and exposed to $1 \mu \mathrm{g} / \mathrm{mL}$ of LPS for $18 \mathrm{~h}$ in the mediums containing koumine. The analysis of IL-1 $\beta$ (A); IL-6 (B); and TNF- $\alpha$ (C) mRNA expressions in the cells were determined by qRT-PCR. The levels of IL- $1 \beta$, IL- 6 , and TNF- $\alpha$ expression were calculated after normalizing signals against the "housekeeping" gene $\beta$-actin, respectively. The data were expressed as mean \pm SD. $(n=3) . \# p<0.01$ vs. control group; ${ }^{* *} p<0.01$ vs. LPS group. - means non-koumine treatment. 


\subsection{Mitochondrial Injury and Cell Apoptosis}

The results showed that LPS treatment deteriorated mitochondrial permeability of RAW 264.7 macrophages, whereas cells exposed to koumine restored mitochondrial membrane potential $(\Delta \Psi \mathrm{m})$, as shown in Figure 6. In order to confirm cellular apoptotic rate, the apoptotic rates were measured by flow cytometry. The results indicated that RAW 264.7 cells without any treatments did not showed obvious apoptosis (Figure 7A). In addition, LPS treatment significantly induced RAW 264.7 cell apoptosis (Figure 7B), whereas apoptotic cell death rate was dose-dependently decreased $(p<0.05)$ by pretreatment with 100, 200, and $400 \mu \mathrm{g} / \mathrm{mL}$ of koumine (Figure 7C-F).

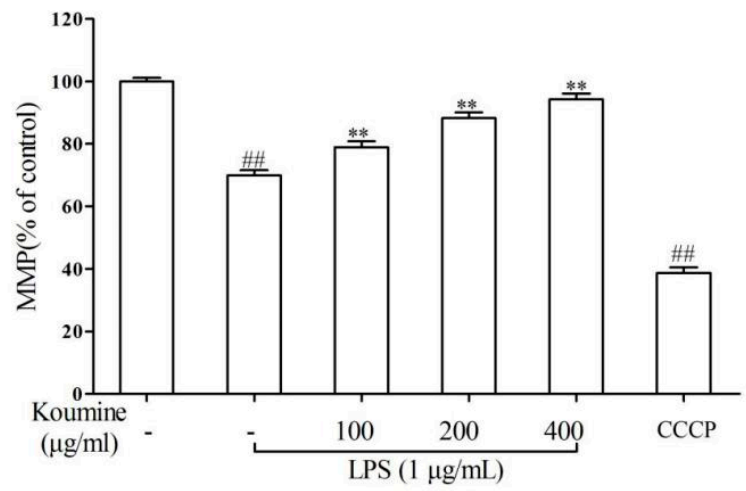

Figure 6. Effects of koumine on mitochondrial membrane potential in LPS-induced RAW 264.7 macrophages. Cells were pretreated with 100 400 $\mu \mathrm{g} / \mathrm{mL}$ koumine for $1 \mathrm{~h}$, and then treated with LPS $(1 \mu \mathrm{g} / \mathrm{mL})$ for $18 \mathrm{~h}$ in the preincubation mediums. JC-1 dye was used to measure $\Delta \Psi \mathrm{m}$ using a fluorescence microplate reader. The $\Delta \Psi \mathrm{m}$ of RAW 264.7 cells in each group were calculated as the fluorescence ratio of red to green. Cell treatments with $40 \mu \mathrm{M}$ carbonylcyanidem-chlorophenyl-hydrazone $(\mathrm{CCCP})$ were used as positive control. The data were expressed as mean $\pm \mathrm{SD}$. $(n=3)$. ${ }^{\#} p<0.01$ vs. control group; ${ }^{* *} p<0.01$ vs. LPS group. - means non-koumine treatment.
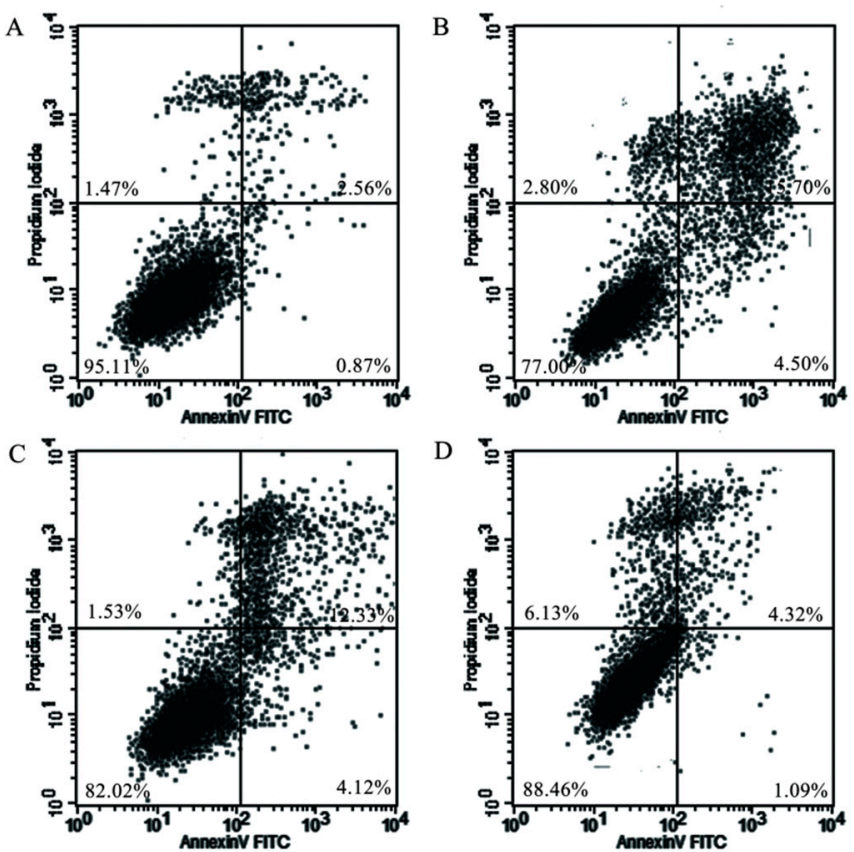

Figure 7. Cont. 

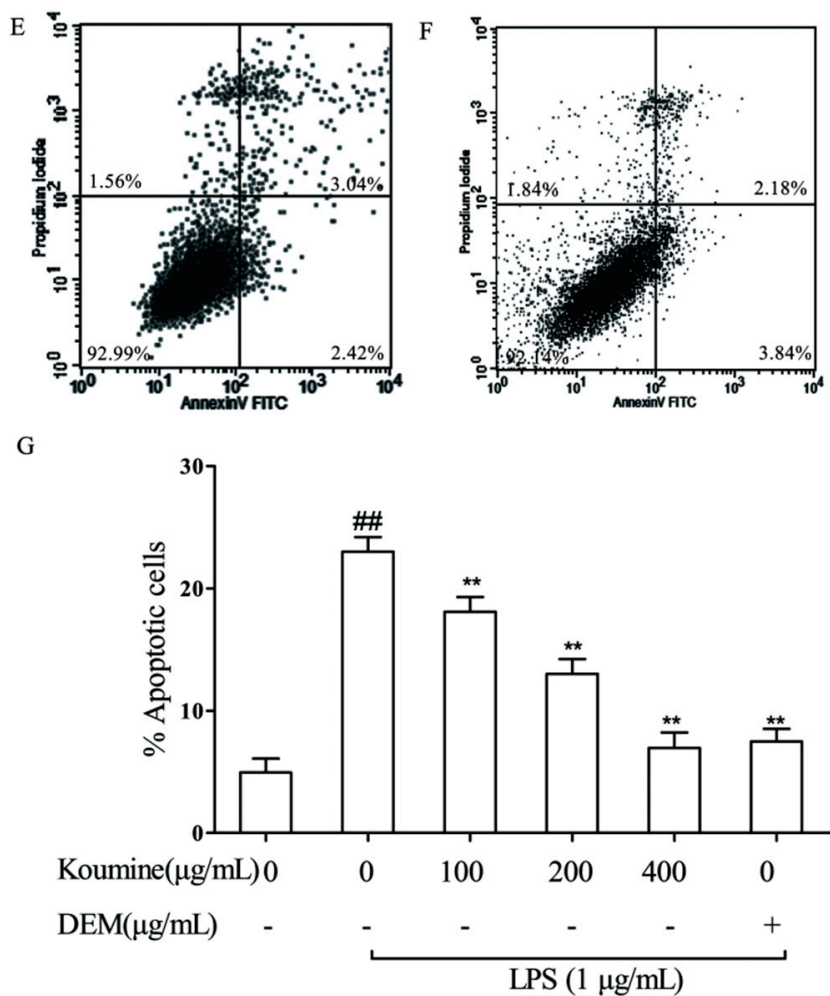

Figure 7. Effects of koumine on LPS-stimulated apoptosis in RAW 264.7 cells measured by flow cytometry. (A) Control; (B) $1 \mu \mathrm{g} / \mathrm{mL}$ LPS; (C-E) cells were precultured withkoumine (100, 200, and $400 \mu \mathrm{g} / \mathrm{mL}$ ) or $10 \mu \mathrm{g} / \mathrm{mL}$ dexamethasone $(\mathbf{F})$ for $1 \mathrm{~h}$, respectively, followed by the incubation of $1 \mu \mathrm{g} / \mathrm{mL}$ LPS for $18 \mathrm{~h}$; (G) koumine dose-dependently reduced the apoptotic rates of RAW 264.7 cells induced by LPS. Cells incubated with $1 \mu \mathrm{g} / \mathrm{mL}$ LPS for $19 \mathrm{~h}$ were used as a positive controls. Data are expressed as the mean $\pm \mathrm{SD}$. $(n=3)$. ${ }^{\# \#} p<0.01$ vs. control group; ${ }^{* *} p<0.01$ vs. LPS group. - means non-dexamethasone treatment, + means $10 \mu \mathrm{g} / \mathrm{mL}$ dexamethasone treatment.

\subsection{Analysis of Caspase Activities}

As shown in Figure 8, our result showed that caspase-9 and -3 activities were significantly higher in LPS-stimulated cells compared to control cells. Koumine pretreatment dose-dependently inhibited caspase- 9 and -3 activities mediated by LPS. The maximum inhibitory effect was at a concentration of $400 \mu \mathrm{g} / \mathrm{mL}$ koumine.

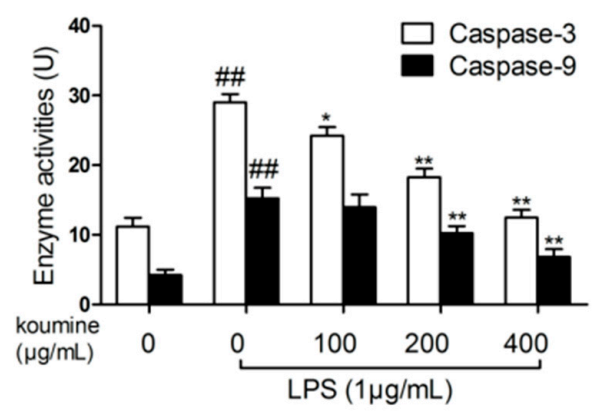

Figure 8. Effects of koumine on caspase activities in LPS-induced RAW 264.7 macrophages. Cells were pretreated with 100-400 $\mu \mathrm{g} / \mathrm{mL}$ koumine or $10 \mu \mathrm{g} / \mathrm{mL}$ dexamethasone (DEM) for $1 \mathrm{~h}$, and then treated with $1 \mu \mathrm{g} / \mathrm{mL}$ LPS for $18 \mathrm{~h}$ in the preincubation mediums. Caspase activities were measured by caspase- 3 and -9 activity assay kits. The data were expressed as mean \pm SD. $(n=3)$. ${ }^{\# \#} p<0.01$ vs. control group; ${ }^{*} p<0.05$ and ${ }^{* *} p<0.01$ vs. LPS group. 


\subsection{Regulation of Apoptosis-Related Proteins}

We determined the expressions of p53, Bcl-2, Bax, and caspase-3 proteins associated with cell apoptosis. As shown in Figure 9, exposure of RAW 264.7 cells to $1 \mu \mathrm{g} / \mathrm{mL}$ LPS led to increase levels of p53, Bax, and cleaved caspase-3 proteins. Meanwhile, the expression of the anti-apoptotic Bcl-2 protein was reduced by LPS treatment. Pretreatment of with 100, 200, and $400 \mu \mathrm{g} / \mathrm{mL}$ koumine attenuated LPS-stimulated the levels of p53 protein (Figure 9B), Bax/Bcl-2 (Figure 9C), and cleaved caspase-3 (Figure 9D). These results suggested that koumine exhibited a protective effect for the LPS-induced RAW 264.7 cells.
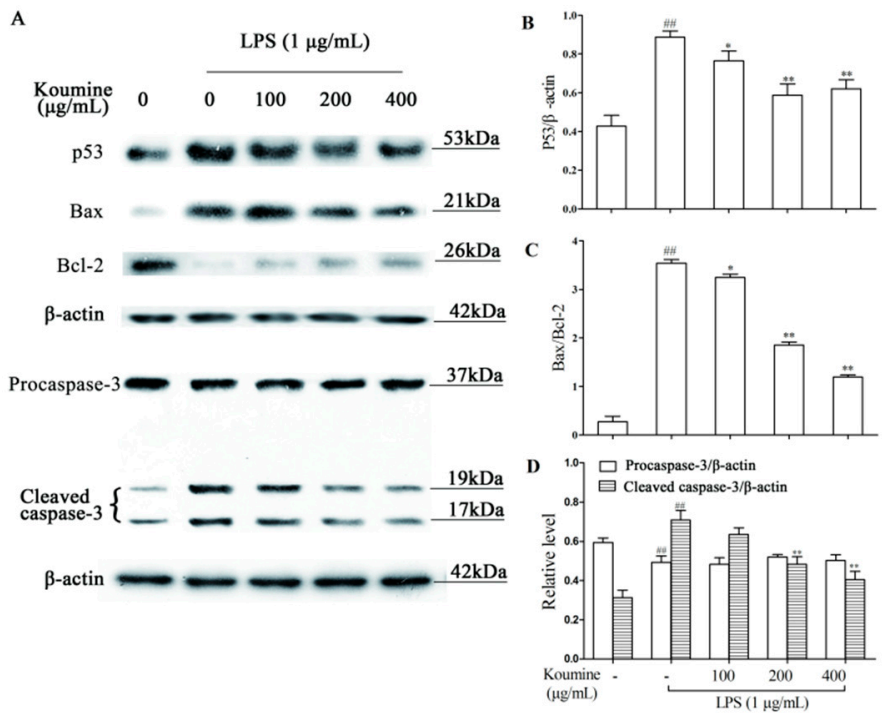

Figure 9. Effects of koumine on apoptosis-related proteins in LPS-induced RAW 264.7 macrophages. Cells were pretreated with 100 400 $\mu \mathrm{g} / \mathrm{mL}$ koumine for $1 \mathrm{~h}$, and then treated with $1 \mu \mathrm{g} / \mathrm{mL}$ LPS in the preincubation mediums for $18 \mathrm{~h}$. The apoptosis-related proteins including Bax, Bcl-2, p53, and caspase-3 were measured by Western bolt. $\beta$-actin are used as internal controls. (A) The expressions of p53, Bax, $\mathrm{Bcl}-2$, and caspase-3 proteins; (B) the quantification histogram of p53 protein level; (C) the ratio of $\mathrm{Bax} / \mathrm{Bcl}-2$ protein level; (D) the quantification histogram of caspase-3 protein level. The data were expressed as mean $\pm \mathrm{SD}$. $(n=3) .{ }^{\# \#} p<0.01$ vs. control group; ${ }^{*} p<0.05$ and ${ }^{* *} p<0.01$ vs. LPS group. - means non-koumine treatment.

\section{Discussion}

This study explored whether koumine protected against LPS-mediated apoptosis in RAW 264.7 macrophages. Furthermore, we revealed the mechanism underlying the koumine protection to LPS-induced apoptosis in RAW 264.7 macrophages. Our study proved that koumine has the ameliorative effect in LPS-mediated apoptosis in a macrophage model. The regulation occurs likely through a mitochondrial caspase-dependent pathway.

ROSs-including hydrogen peroxide $\left(\mathrm{H}_{2} \mathrm{O}_{2}\right)$, hydroxyl radical $\left(\mathrm{OH}^{-}\right)$, and superoxide anion $\left(\mathrm{O}^{2-}\right)$ - are physiologically produced at a basal rate. Much evidence supports that a ROS-dependent oxidative stress response is an important mechanism involved in the innate immune response activated by LPS. Previous studies indicated that there is a close connection between oxidative stress machinery and inflammatory signaling [17]. Excessive oxidative stress leads to an unavoidable consequence of inflammatory reaction —even in serious intact cells-and tissue injury [18]. It has been proven that LPS administration stimulates production of hydroxyl radical in the early phase of inflammation and damages brain tissue after a longer exposure to LPS [19]. A growing body of experimental work indicates that oxidative stress mediated by LPS is associated with the pathogenesis of inflammatory diseases. Therefore, suppression of LPS-induced oxidative stress was regarded 
as a key strategy for inflammatory disease prevention. Botanical extracts, especially alkaloids, have been shown to possess anti-oxidative and anti-inflammatory activities. It has been well established that Taraxacum officinale Weber extracts suppressed oxidative stress and inflammatory responses via promotion of de novo synthesis of antioxidative enzymes and inhibits the expression of iNOS [20]. Alkaloids exacted from Chelidonium majus exhibited significant inhibitory effect on the LPS-mediated the production of NO and the induction of iNOS in RAW 264.7 macrophage cells, suggesting that those alkaloids prevented the iNOS-mediated NO syntheses at the transcriptional level [21]. Differing with these studies, Lee et al. found that 13 alkyl-substituted berberine alkaloids concentration-dependently suppressed NO production in LPS-treated splenic macrophages, but did not affect TNF- $\alpha$ protein/mRNA expression and iNOS mRNA expressions [22]. In this study, the results showed that preculture with koumine obviously reduced ROS release, iNOS level, suppressed the mRNA expressions of inflammatory cytokines (TNF- $\alpha$, IL-1 $\beta$, and IL-6), and restored cell growth in LPS-stimulated RAW 264.7 cells, indicating that koumine exerts antioxidative and inflammatory activities. The results are different with Wang et al. who assessed the effects of koumine on the CD4 ${ }^{+}$ $\mathrm{T}$ cell growth [23]. They demonstrated $20-200 \mathrm{mg} / \mathrm{mL}$ koumine significantly reduced cell growth and IL-2 level in ConA- or PHA-mediated murine lymphocytes as compared with the controls due to its immunosuppressive effect and reduction of IL-2 secretion. Numerous studies indicate that $\mathrm{CD}^{+} \mathrm{T}$ lymphocytes and macrophages regulate the release of different types of cytokines which exert different function. $T$ cells and IL-2 pays a viral role in stimulating immune response and inhibiting autoimmunity. $\mathrm{CD}^{+} \mathrm{T}$ cells could differentiate into effector Th1 cells which predominantly secrete IL-2, IL-12, and interferon-gamma (IFN- $\gamma$ ) to take part in cell-mediated inflammatory reactions [24-26]. Moreover, IL-2 receptors (IL-2Rs) stimulate proliferation of stimulated CD4 ${ }^{+}, \mathrm{CD}^{+}, \mathrm{CD}^{-}{ }^{-} \mathrm{CD}^{-}$, and $\gamma \delta$ subsets of lymphocytes with maintenance of functional activity $[27,28]$. However, using IL-2, T cells can be expanded in vivo which in turn perform strong immunosuppression [29]. High-dose IL-2 as a treatment for people with cancer might product toxic reactions, like a vascular leak in the spleen, liver, or lungs [30,31], and low dose IL-2 could help inhibiting immunosuppression after transplantation [32]. On the other hand, some cytokines such as TNF- $\alpha$, IL-1 $\beta$, and IL- 6 regulate the differentiation of various cells including macrophages in the immune system via various inflammatory pathways to trigger immune reaction as presented in this study. Thus, we can deduce that koumine might play a dual regulatory role in innate immunity.

Apoptosis is a type I form of programmed cell death that is induced by various intracellular stimuli, including oxidative stress, bacteria invasion, and DNA damage, via outer mitochondrial membrane permeabilization [33]. Mitochondria-unique organelles for energy transformation-are crucial for cellular proliferation, regulation of the cellular redox state, as well as cell apoptosis. The mitochondria respiratory chain is a major site of ROS production in the cells, and mitochondria are particularly vulnerable to oxidative stress after mitochondrial dysfunction, depolarization of mitochondrial membrane potential $(\Delta \Psi \mathrm{m})$, and the opening of the mitochondrial permeability transition pore complex has been induced. Furthermore, the expressions of pro- and anti-apoptotic Bcl-2 family proteins which belong to the intrinsic mitochondrial apoptotic pathway are changed. Subsequently, various caspases are stimulated and cell apoptosis is irreversible, indicating that ROS as mediators produced by the mitochondria appear to be associated with early and late steps of the regulation of cell apoptosis [34,35]. In some cells, the anti-apoptotic Bcl-2 family proteins prevent activations of caspases at their upstream to prevent apoptosis [36]. It was evident from Fleury et al. [37] that suppression of apoptosis through anti-apoptotic Bcl-xL and Bcl-2 is relative to a reduction of the cellular redox potential and/or a protection against ROS. Macrophages make major contributions to the homeostasis of the host and inflammatory immunopathology. They rapidly respond to invasion to promote immune responses and conversely, repair injured tissue in the aftermath of an immune response by downmodulating inflammatory responses [38]. Rapid efferocytic apoptosis of macrophages with effective clearance could inhibit proinflammatory response, such as production of large amounts of mediators (TNF- $\alpha$, IL-1, and IL-6), nitric oxide, and reactive oxygen 
intermediaries. The action is aimed at decrease of lesion size and cellularity. In advanced lesions, the apoptotic macrophages are not efficiently cleared by efferocytosis. The apoptotic macrophages that accumulate eventually undergo secondary necrosis, because they are too much to clear out [39]. In this study, we determined that LPS significantly increased RAW 264.7 cell apoptosis. We also found that LPS decreased mitochondrial membrane potential, promoted activations of caspase- 3 and caspase- 9 , increased expressions of Bax and cleaved caspase-3 and decreased level of Bcl-2 protein in RAW 264.7 cells, suggesting that LPS likely induced apoptosis through caspase-dependent mitochondrial death pathway. This result is in agreement with results already obtained by Langford et al. [40]. However, koumine pretreatment reversed this effect. The data showed that RAW 264.7 macrophages pretreated with koumine suppressed the LPS-stimulated mitochondrial apoptotic pathway including structural mitochondrial damage, decrease of expression of Bcl-2 protein, activation of caspase- 9 and -3 , and increase of expressions of Bax and caspase-3 proteins.

The nuclear transcription factor p53 can control the intrinsic pathway of apoptosis related to mitochondria. A host of various p53-induced genes including PERP, Bax, IGF-BP3, and Fas / Apo-1 were proposed to play a role in p53-mediated cell death [41]. P53-mediated transcription-independent apoptosis needs to involve Bax, mitochondrial cytochrome $\mathrm{c}$ release and caspase activation in the case nucleus is absence, indicating that p53 can activate the apoptotic program directly from the cytoplasm [42]. In the present study, pretreatment with koumine reduced LPS-induced activation p53, suggesting koumine alleviated apoptosis through regulation of p53 pathway, which results in the decrease of mitochondrial membrane potential, suppression of caspase cascade, and-ultimately-amelioration of cell apoptosis.

\section{Materials and Methods}

\subsection{Materials}

The koumine was purechased from Shanghai Kang Biao chemicals Co., LTD ( $\geq 98 \%$ purity; Shanghai, China). LPS (from E. coli, isotype 0111:B4) was purchased from Sigma (St. Louis, MO, USA, Cat\# L2630-10MG, Lot\# 114M4009v). A $1 \mathrm{mg} / \mathrm{mL}$ stock solution of LPS was prepared in cell culture medium and further diluted to a final concentration of $1 \mu \mathrm{g} / \mathrm{mL}$. Caspase- 3 and -9 activity assay kits were purchased from Beyotime (Nanjing, China). Primary antibodies against Bax, Bcl-2, p53, and $\beta$-actin were from BD Pharmingen (San Diego, CA, USA), Primary antibodies against caspase-3 was purchased from CST (Danvers, MA, USA). Polyvinylidene fluoride (PVDF) membrane and Amersham ECL Advance Western blot detection kits were obtained from GE Heathcare Life (Logan, UT, USA).

\subsection{Cell Culture}

Murine macrophage RAW 264.7 cells were obtained from Conservation Genetics CAS Kunming Cell Bank, and subcultured to confluence in Dulbecco's modified Eagle's medium (DMEM; Gibco, GrandIsland, NY, USA) containing $100 \mathrm{U} / \mathrm{mL}$ penicillin (HyClone, Logan, UT, USA), 10\% $(v / v)$ fetal bovine serum (Gibco, GrandIsland, NY, USA), and $100 \mu \mathrm{g} / \mathrm{mL}$ streptomycin (HyClone, Logan, UT, USA) in a humidified $5 \% \mathrm{CO}_{2}$ incubator at $37^{\circ} \mathrm{C}$.

\subsection{MTT Assay}

Cell cytotoxicity was evaluated by MTT (3-(4,5-Dimethylthiazol-2-yl)-2,5-Diphenyltetrazolium Bromide) assay. For cell cytotoxic assay, RAW 264.7 cells $\left(3 \times 10^{4}\right.$ cells per well in 96 -well culture plates) were incubated for $24 \mathrm{~h}$, or pre-incubated with 100, 200, or $400 \mu \mathrm{g} / \mathrm{mL}$ koumine for $1 \mathrm{~h}$ after $1 \mu \mathrm{g} / \mathrm{mL}$ LPS treatment for $18 \mathrm{~h}$. MTT (the final concentration of $0.5 \mathrm{mg} / \mathrm{mL}$ ) was added for $4 \mathrm{~h}$. Subsequently, dimethyl sulfoxide (DMSO) was added to dissolve the formazan crystals after removing the culture medium. Data was read immediately at $570 \mathrm{~nm}$. The optical density of formazan formed in control was taken as $100 \%$ of cell viability. Samples were measured in quintuplicate, and the experiment was repeated three times. 


\subsection{Determination of $R O S$}

The level of intracellular ROS was determined by a fluorometric assay using the ROS sensitive fluorescent dye DCFH-DA (Beyotime, Nanjing, China) as the probe. The prepared RAW 264.7 macrophages $\left(1 \times 10^{6}\right.$ cells/well) were pretreated with 100,200 , and $400 \mu \mathrm{g} / \mathrm{mL}$ koumine for $1 \mathrm{~h}$ followed by $1 \mu \mathrm{g} / \mathrm{mL}$ of LPS exposure in the preincubation mediums for $18 \mathrm{~h}$. Samples were then treated with $10 \mu \mathrm{m}$ DCFH-DA for $30 \mathrm{~min}$ in the dark. After cells were washed twice with PBS, fluorescence was measured at $488 \mathrm{~nm}$ excitation and $525 \mathrm{~nm}$ emission wavelength in a SpectraMax ${ }^{\circledR}$ M2 Microplate Reader (Molecular Devices, Sunnyvale, CA, USA), respectively. Samples were measured in triplicate, and the experiment was repeated three times.

\section{5. iNOS, IL-1 $\beta, I L-6$, and TNF- $\alpha$ qRT-PCR Assay}

Cells were seeded at a density of $2 \times 10^{6}$ cells/well in 6-well plates. After stimulation, RNA was isolated from RAW 264.7 cells using Trizol ${ }^{\circledR}$ reagent (Invitrogen, Carlsbad, CA, USA) according to the manufacturer's instructions. $1 \mu \mathrm{g}$ of total RNA was reverse-transcribed by the cDNA Synthesis Kit (Takara, Shiga, Japan). The quantification of relative mRNA concentrations was measured by qRT-PCR using a 7500 Fast Real-Time PCR System (Applied Biosystems, Foster City, CA, USA) and the SYBR green Plus reagent kit (Roche Applied Science, Mannheim, Germany), as described elsewhere [43]. The PCR mixtures were subjected to an initial denaturation of $95^{\circ} \mathrm{C}$ for $10 \mathrm{~min}$, followed by 40 cycles of amplification (denaturation at $95^{\circ} \mathrm{C}$ for $10 \mathrm{~s}$, annealing at $59^{\circ} \mathrm{C}$ for $50 \mathrm{~s}$, and elongation at $72{ }^{\circ} \mathrm{C}$ for $30 \mathrm{~s}$ ). A final elongation at $72{ }^{\circ} \mathrm{C}$ for $10 \mathrm{~min}$ was performed. The primer sequences were as follows: iNOS, forward (5'-AAC ATC AGG TCG GCC ATC ACT- $\left.3^{\prime}\right)$ and reverse (5'-CCA GAG GCA GCA CAT CAA AGC- $\left.3^{\prime}\right)$; IL-1 $\beta$, forward (5'-CGT TCC CAT TAG ACA ACT GCA-3') and reverse (5'-GGT ATA GAT TCT TTC CTT TGA GGC-3'); IL-6, forward (5'-ACG GCC TTC CCT ACT TC-3') and reverse (5'-TTC CAC GAT TTC CCA GA - $3^{\prime}$ ); TNF- $\alpha$, forward (5'-TGA GGA CCA AGG AGG AAA GTA TGT- $\left.3^{\prime}\right)$ and reverse ( $5^{\prime}$-CAG CAG GTG TCG TTG TTC AGG-3'); $\beta$-actin, forward ( $5^{\prime}$-CAT CCT GCG TCT GGA CCT GG-3') and reverse (5'-TAA TGT CAC GCA CGA TTT CC-3'). Samples were measured in triplicate, and each reaction was run three times.

\subsection{Mitochondrial Membrane Potential}

Cells $\left(5 \times 10^{5}\right.$ cells/well) were seeded in 12-well tissue culture plates overnight and then pretreated with 100, 200, and $400 \mu \mathrm{g} / \mathrm{mL}$ koumine for $1 \mathrm{~h}$ followed by $1 \mu \mathrm{g} / \mathrm{mL}$ of LPS exposure in the preincubation mediums for $18 \mathrm{~h}$. Subsequently, mitochondrial membrane potential assay kit with JC-1 (Beyotime, Nanjing, China) was used to measure the mitochondrial membrane potential $(\triangle \psi \mathrm{m})$ of RAW 264.7 cells according to the manufacturer's directions. Briefly, after cells were washed with PBS twice, cells were loaded with JC- 1 for $30 \mathrm{~min}$ at $37^{\circ} \mathrm{C}$ in the dark. Following staining, JC-1 dyeing buffer was pre-cooled to $4{ }^{\circ} \mathrm{C}$, and the cells were rinsed twice with it. Fluorescent intensity of both

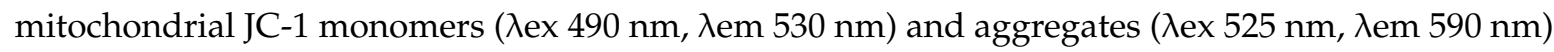
were detected using SpectraMax ${ }^{\circledR}$ M2 Microplate Reader (Molecular Devices, Sunnyvale, CA, USA), respectively. As a positive control, mitochondria were depolarized by treating macrophage with $40 \mu \mathrm{M}$ carbonylcyanidem-chlorophenyl-hydrazone (CCCP) at $37^{\circ} \mathrm{C}$ for $10 \mathrm{~min}$. Samples were measured in triplicate, and the experiment was repeated three times.

\subsection{Flow Cytometry}

Cells were seeded in 24-well plates at a density of $0.5 \times 10^{6}$ cells per well for $24 \mathrm{~h}$. These cells were pre-incubated with koumine $(100,200$ and $400 \mu \mathrm{g} / \mathrm{mL})$ or $10 \mu \mathrm{g} / \mathrm{mL}$ dexamethasone (DEM) for $1 \mathrm{~h}$ after $18 \mathrm{~h}$ of $1 \mu \mathrm{g} / \mathrm{mL}$ LPS treatment. Then cell apoptosis was determined using an annexin V-fluorescein isothiocyanate (FITC) detection kit (Beyotime, Nanjing, China), as described in the protocol. Briefly, cells were trypsinized, washed in PBS, and resuspended in $195 \mu \mathrm{L}$ in binding buffer (10 mM HEPES (hydroxyethyl piperazineethanesulfonic acid), pH 7.4, $140 \mathrm{mM} \mathrm{NaCl}, 2.5 \mathrm{mM}$ 
$\left.\mathrm{CaCl}_{2}\right)$. Cell suspension $\left(1 \times 10^{6}\right.$ cells $\left./ \mathrm{mL}\right)$ was incubated with $5 \mu \mathrm{L}$ annexin $\mathrm{V}$ conjugated to FITC cells and $10 \mu \mathrm{L}$ propidiumiodide (PI) for $15 \mathrm{~min}$ at $25^{\circ} \mathrm{C}$ without light. Cells were examined with Becton Dickinson FACScan analysis software (BD Immunocytometry Systems; BD Biosciences, Becton Dickinson, Mountain View, CA, USA). Cells incubated with $1 \mu \mathrm{g} / \mathrm{mL}$ LPS for $19 \mathrm{~h}$ were used as a positive control. Samples were measured in triplicate.

\subsection{Caspase-3 and -9 Activities}

The Caspase-3 and Caspase-9 Activity Kits (Beyotime, Nanjing, China) were used to measure the activities of caspase- 3 and -9 , which is based on spectophotometric detection of the chromophore $p$-nitroaniline ( $p \mathrm{NA}$ ) after cleavage from the labeled substrate acetyl-Asp-Glu-Val-Asp $p$-nitroanilide (Ac-DEVD- $p$ NA) and acetyl-Leu-Glu-His-Asp $p$-nitroanilide (Ac-LEHD- $p$ NA), respectively. Cells were pre-incubated with 100, 200, and $400 \mu \mathrm{g} / \mathrm{mL}$ koumine or $10 \mu \mathrm{g} / \mathrm{mL}$ dexamethasone (DEM) for $1 \mathrm{~h}$ after $18 \mathrm{~h}$ of $1 \mu \mathrm{g} / \mathrm{mL}$ LPS treatment, respectively. For assays, $1 \times 10^{6}$ cells were washed with cold PBS and lysed on ice. After centrifugation at $16,000-20,000 \mathrm{~g}$ for $15 \mathrm{~min}$ at $4{ }^{\circ} \mathrm{C}$, caspase were assays performed in 96-well plates by incubating $50 \mu \mathrm{L}$ supernatant per sample with $10 \mu \mathrm{L}$ caspase substrate (Ac-DEVD- $p$ NA or Ac-LEHD- $p$ NA) $(2 \mathrm{mM})$ and $40 \mu \mathrm{L}$ reaction buffer (1\% NP-40, $20 \mathrm{mM}$ Tris-HCl (pH 7.5), $137 \mathrm{mM} \mathrm{Nacl}$ and $10 \%$ glycerol) for $1.5 \mathrm{~h}$ at $37^{\circ} \mathrm{C}$. Absorbance was read at $405 \mathrm{~nm}$ using a microplate reader (MK3, Thermo, Waltham, MA, USA). Caspase-3 activity was expressed as the change in enzyme activity relative to untreated control cultures.

\subsection{Western Blot Analysis}

Cells $\left(1 \times 10^{6}\right.$ cells/well) were seeded in 6-well plates for $24 \mathrm{~h}$, and pretreated with 100 , 200, and $400 \mu \mathrm{g} / \mathrm{mL}$ koumine for $1 \mathrm{~h}$ followed by $1 \mu \mathrm{g} / \mathrm{mL}$ of LPS exposure in the preincubation mediums. After $18 \mathrm{~h}$ incubation, the cellular proteins were extracted using lysis buffer containing 1\% NP-40, $150 \mathrm{mmol} / \mathrm{L} \mathrm{NaCl}, 50 \mathrm{mmol} / \mathrm{L}$ Tris- $\mathrm{HCl}, \mathrm{pH}$ 8.0, 0.5\% sodium deoxycholate, and $0.1 \%$ SDS. The concentration of total proteins was measured using the bicinchoninic acid assay (BCA) (Pierce, Rockford, IL, USA). Equal amounts of protein samples were separated by $10 \%$ sodium dodecyl sulfate polyacrylamide gel electrophoresis, transferred onto PVDF membranes, and blocked by incubating the membrane in blocking solution containing $5 \%$ nonfat milk (Yili, Tianjin, China) for $1 \mathrm{~h}$ at room temperature. The PVDF membranes were washed, followed by incubation with the diluted respective primary antibodies (anti- $\beta$-actin, anti-caspase-3, anti-Bax, anti-p53, and anti-Bcl-2) at $4{ }^{\circ} \mathrm{C}$ overnight. The membrane was washed with PBST followed by incubation with the secondary antibody for $1 \mathrm{~h}$ at room temperature. Subsequently, the protein bands were detected using ECL reagents. Chemiluminescent signals were detected and analyzed using the ChemiDoc XRS imaging system (Bio-Rad, Hercules, CA, USA).

\subsection{Statistical Analysis}

Data were expressed as mean $\pm \mathrm{SD}$. Data were analyzed using LSD tests and one-way ANOVA using SPSS 19 software (Version 13.0; IBM SPSS, Inc., Chicago, IL, USA). A $p$ values $<0.05$ was considered statistically significant.

\section{Conclusions}

Koumine, an active alkaloid of G. elegans, protects RAW 264.7 macrophage against LPS-induced cell apoptosis by inhibiting intracellular ROS production and p53 activation, followed by interfering with induction of the mitochondrial caspase-dependent pathway.

Acknowledgments: This study is supported by the National Natural Science Foundation of China (Grant No. 31572563; Grant No. 31501484; Grant No. 31302157) and the Hunan Provincial Natural Science Foundation of China (Grant No. 2016JJ3081). 
Author Contributions: Zhi-Hang Yuan and Zhi-Liang Sun conceived and designed the experiments. Zhi-Hang Yuan, Zeng-Enni Liang, Jing Wu, and Jin-E Yi performed the research. Xiao-Jun Chen and Zhi-Liang Sun analyzed the data. Zhi-Hang Yuan wrote the paper. Zeng-Enni Liang revised the paper. All the authors read and approved the final manuscript.

Conflicts of Interest: The authors declare no conflict of interest.

\section{References}

1. Wyllie, A.H.; Kerr, J.F.; Currie, A.R. Cell death: The significance of apoptosis. Int. Rev. Cytol. 1980, 68, 251-306. [PubMed]

2. Wyns, H.; Plessers, E.; de Backer, P.; Meyer, E.; Croubels, S. In vivo porcine lipopolysaccharide inflammation models to study immunomodulation of drugs. Vet. Immunol. Immunopathol. 2015, 166, 58-69. [CrossRef] [PubMed]

3. Barton, G.M.; Medzhitov, R. Toll-like receptor signaling pathways. Science 2003, 300, 1524-1525. [CrossRef] [PubMed]

4. Campo, G.M.; Avenoso, A.; Campo, S.; D'Ascola, A.; Traina, P.; Sama, D.; Calatroni, A. Glycosaminoglycans modulate inflammation and apoptosis in LPS-treated chondrocytes. J. Cell. Biochem. 2009, 106, 83-92. [CrossRef] [PubMed]

5. Choi, K.B.; Wong, F.; Harlan, J.M.; Chaudhary, P.M.; Hood, L.; Karsan, A. Lipopolysaccharide mediates endothelial apoptosis by a FADD-dependent pathway. J. Biol. Chem. 1998, 237, 20185-20188. [CrossRef]

6. Fielhaber, J.A.; Carroll, S.F.; Dydensborg, A.B.; Shourian, M.; Triantafillopoulos, A.; Harel, S.; Hussain, S.N.; Bouchard, M.; Qureshi, S.T.; Kristof, A.S. Inhibition of mammalian target of rapamycin augments lipopolysaccharide-induced lung injury and apoptosis. J. Immunol. 2012, 188, 4535-4542. [CrossRef] [PubMed]

7. Namisaki, T.; Yoshiji, H.; Kojima, H.; Yoshii, J.; Ikenaka, Y.; Noguchi, R.; Sakurai, S.; Yanase, K.; Kitade, M.; Yamazaki, M.; et al. Salvage effect of the vascular endothelial growth factor on chemically induced acute severe liver injury in rats. J. Hepatol. 2006, 44, 568-575. [CrossRef] [PubMed]

8. Yang, S.; Gong, Q.H.; Wu, Q.; Li, F.; Lu, Y.F.; Shi, J.S. Alkaloids enriched extract from Dendrobium nobile Lindl. attenuates tau protein hyperphosphorylation and apoptosis induced by lipopolysaccharide in rat brain. Phytomedicine 2014, 21, 712-716. [CrossRef] [PubMed]

9. Lu, J.S.; Liu, Y.Q.; Li, M.; Li, B.S.; Xu, Y. Protective effects and its mechanisms of total alkaloids from rhizome Coptis chinensis on Helicobacter pylori LPS induced gastric lesion in rats. China J. Chin. Mater. Med. 2007, 32, 1333-1336.

10. Dutt, V.; Thakur, S.; Dhar, V.J.; Sharma, A. The genus Gelsemium: An update. Pharmacogn. Rev. 2010, 4, 185-194. [CrossRef] [PubMed]

11. Liu, H.; Xu, Y.; Shi, D.M.; Yu, C.X. Pharmacognostical study on the Gelsemium elegans Benth. from Fuzhou. Strait Pharm. J. 2008, 20, 62-64.

12. Wang, Y.H.; Wu, S.S.; Chen, Z.C.; Zhang, H.; Zhao, W.L. Inhibitory effects of cytochrome P450 enzymes CYP1A2, CYP2A6, CYP2E1 and CYP3A4 by extracts and alkaloids of Gelsemium elegans roots. J. Ethnopharmacol. 2015, 166, 66-73. [CrossRef] [PubMed]

13. Wu, D.R.; Qin, R.; Cai, J.; Chi, D.B. Antitumor activity of koumine in vitro and vivo. Pharmacol. Clin. Chin. Mater. Med. 2006, 22, 6-8.

14. Liu, M.; Huang, H.H.; Yang, J.; Su, Y.P.; Lin, H.W.; Lin, L.Q.; Liao, W.J.; Yu, C.X. The active alkaloids of Gelsemium elegans benth. are potent anxiolytics. Psychopharmacology 2013, 225, 839-851. [CrossRef] [PubMed]

15. Tan, J.Q.; Qiu, C.Z.; Zheng, L.Z. Analgesic effect and no physical dependence of Gelsemium elegans Benth. Pharmacol. Clin. Chin. Mater. Med. 1988, 4, 24-28.

16. Xu, Y.; Qiu, H.Q.; Liu, H.; Liu, M.; Huang, Z.Y.; Yang, J.; Su, Y.P.; Yu, C.X. Effects of koumine, an alkaloid of Gelsemium elegans Benth., on inflammatory and neuropathic pain models and possible mechanism with allopregnanolone. Pharmacol. Biochem. Behav. 2012, 101, 504-514. [CrossRef] [PubMed]

17. Bondia-Pons, I.; Ryan, L.; Martinez, J.A. Oxidative stress and inflammation interactions in human obesity. J. Physiol. Biochem. 2012, 68, 701-711. [CrossRef] [PubMed]

18. Cencioni, C.; Spallotta, F.; Martelli, F.; Valente, S.; Mai, A.; Zeiher, A.M.; Gaetano, C. Oxidative stress and epigenetic regulation in ageing and age-related diseases. Int. J. Mol. Sci. 2013, 14, 17643-17663. [CrossRef] [PubMed] 
19. Noworyta-Sokołowska, K.; Górska, A.; Gołembiowska, K. LPS-induced oxidative stress and inflammatory reaction in the rat striatum. Pharm. Rep. 2013, 65, 863-869. [CrossRef]

20. Park, C.M.; Park, Y.J.; Noh, K.H.; Shin, J.H.; Song, Y.S. Taraxacum officinale Weber extracts inhibit LPS-induced oxidative stress and nitric oxide production via the NF-KB modulation in RAW 264.7 cells. J. Ethnopharmacol. 2011, 133, 834-842. [CrossRef] [PubMed]

21. Park, J.E.; Cuong, T.D.; Hung, T.M.; Lee, I.; Na, M.K.; Kim, J.C.; Ryoo, S.; Lee, J.H.; Choi, J.S.; Woo, M.H.; et al. Alkaloids from Chelidonium majus and their inhibitory effects on LPS-induced NO production in RAW264. 7 cells. Bioorg. Med. Chem. Lett. 2011, 21, 6960-6963. [CrossRef] [PubMed]

22. Lee, D.U.; Kang, Y.J.; Park, M.K.; Lee, Y.S.; Seo, H.G.; Kim, T.S.; Kim, C.H.; Chang, K.C. Effects of 13-alkyl-substituted berberine alkaloids on the expression of COX-II, TNF- $\alpha$, iNOS, and IL-12 production in LPS-stimulated macrophages. Life Sci. 2003, 73, 1401-1412. [CrossRef]

23. Wang, Z.R.; Huang, C.Q.; Zhang, Z.Y.; Zhang, L.L.; Lin, J.M. Effect of koumine on proliferation of murine $\mathrm{CD}^{+} \mathrm{T}$ cells purified by magnetic-activated cell sorting in vitro. J. First Mil. Med. Univ. 2005, 25, 562-564.

24. Mchugh, S.M.; Rifkin, I.R.; Deighton, J.; Wilsion, A.B.; Lachamnn, P.J.; Lockwood, C.M. The immunosuppressive drug thalidomide induces T helper cell type 2 (Th2) and concomitantly inhibits Thl cytokine production in mitogen- and antigen-stimulated human peripheral blood mononuclear cell cultures. Clin. Exp. Immunol. 1995, 99, 160-167. [CrossRef] [PubMed]

25. Fehniger, T.A.; Cooper, M.A.; Nuovo, G.J.; Cella, M.; Facchetti, F.; Colonna, M.; Caligiuri, M.A. CD56 ${ }^{\text {bright }}$ natural killer cells are present in human lymph nodes and are activated by T cell-derived IL-2: A potential new link between adaptive and innate immunity. Blood 2003, 101, 3052-3057. [CrossRef] [PubMed]

26. Rosenberg, S.A. IL-2: The first effective immunotherapy for human cancer. J. Immunol. 2014, 192, 5451-5458. [CrossRef] [PubMed]

27. Sittrich, A.B.; Haftmann, C.; Sgouroudis, E.; Kühl, A.A.; Hegazy, A.N.; Panse, I.; Riedel, R.; Flossdorf, M.; Dong, J.; Fuhrmann, F.; et al. The microRNA miR-182 is induced by IL-2 and promotes clonal expansion of activated helper T lymphocytes. Nat. Immunol. 2010, 11, 1057-1062. [CrossRef] [PubMed]

28. Balsamo, M.; Vermi, W.; Parodi, M.; Pietra, G.; Manzini, C.; Queirolo, P.; Lonardi, S.; Augugliaro, R.; Moretta, A.; Facchetti, F.; et al. Melanoma cells become resistant to NK-cell-mediated killing when exposed to NK-cell numbers compatible with NK-cell infiltration in the tumor. Eur. J. Immunol. 2012, 42, 1833-1842. [CrossRef] [PubMed]

29. Melencio, L.; Mckallip, R.J.; Guan, H.; Ramakrishnan, R.; Jain, R.; Nagarkatti, P.S.; Nagarkatti, M. Role of $\mathrm{CD}^{+} \mathrm{CD} 25^{+} \mathrm{T}$ regulatory cells in IL-2-induced vascular leak. Int. Immunol. 2006, 18, 1461-1471. [CrossRef] [PubMed]

30. Gallagher, D.C.; Bhatt, R.S.; Parikh, S.M.; Patel, P.; Seery, V.; Mcdermott, D.F.; Atkins, M.B.; Sukhatme, V.P. Angiopoietin 2 is a potential mediator of high-dose interleukin 2-induced vascular leak. Clin. Cancer Res. 2007, 13, 2115-2120. [CrossRef] [PubMed]

31. Guan, H.; Singh, N.P.; Singh, U.P.; Nagarkatti, P.S.; Nagarkatti, M. Resveratrol prevents endothelial cells injury in high-dose interleukin-2 therapy against melanoma. PLoS ONE 2012, 7, e35650. [CrossRef] [PubMed]

32. Rouse, M.; Nagarkatti, M.; Nagarkatti, P.S. The role of IL-2 in the activation and expansion of regulatory T-cells and the development of experimental autoimmune encephalomyelitis. Immunobiology 2013, 216, 674-682. [CrossRef] [PubMed]

33. Toren, D.; Barzilay, T.; Tacutu, R.; Lehmann, G.; Muradian, K.K.; Fraifeld, V.E. MitoAge: A database for comparative analysis of mitochondrial DNA, with a special focus on animal longevity. Nucl. Acids Res. 2016, 44, D1262-D1265. [CrossRef] [PubMed]

34. Novoderezhkina, E.A.; Zhivotovsky, B.D.; Gogvadze, V.G. Induction of unspecific permeabilization of mitochondrial membrane and its role in cell death. Mol. Biol. 2016, 50, 51-68. [CrossRef]

35. Barnwal, B.; Karlberg, H.; Mirazimi, A.; Tan, Y.J. The non-structural protein of crimean-congo hemorrhagic fever virus disrupts the mitochondrial membrane potential and induces apoptosis. J. Biol. Chem. 2016, 291, 582-592. [CrossRef] [PubMed]

36. Deckwerth, T.L.; Easton, R.M.; Knudson, C.M.; Korsmeyer, S.J.; Johnson, E.M. Placement of the BCL2 family member BAX in the death pathway of sympathetic neurons activated by trophic factor deprivation. Exp. Neurol. 1998, 152, 150-162. [CrossRef] [PubMed]

37. Fleury, C.; Mignotte, B.; Vayssière, J.L. Mitochondrial reactive oxygen species in cell death signaling. Biochimie 2002, 84, 131-141. [CrossRef] 
38. Cohen, H.B.; Mosser, D.M. Extrinsic and intrinsic control of macrophage inflammatory responses. J. Leukoc. Biol. 2013, 94, 913-919. [CrossRef] [PubMed]

39. Seimon, T.; Tabas, I. Mechanisms and consequences of macrophage apoptosis in atherosclerosis. J. Lipid Res. 2009, 50, S382-S387. [CrossRef] [PubMed]

40. Langford, M.P.; McGee, D.J.; Ta, K.H.; Redens, T.B.; Texada, D.E. Multiple caspases mediate acute renal cell apoptosis induced by bacterial cell wall components. Ren. Fail. 2011, 33, 192-206. [CrossRef] [PubMed]

41. Ding, R.; Jin, S.; Pabon, K.; Scotto, K.W. A role for ABCG2 beyond drug transport: Regulation of autophagy. Autophagy 2016, 12, 737-751. [CrossRef] [PubMed]

42. Bernard, A.; Klionsky, D.J. Rph1 mediates the nutrient-limitation signaling pathway leading to transcriptional activation of autophagy. Autophage 2016, 11, 718-719. [CrossRef] [PubMed]

43. Hinića, V.; Brodarda, I.; Thomanna, A.; Cvetnićc, Ž.; Makayad, P.V.; Freyb, J.; Abril, C. Novel identification and differentiation of Brucella melitensis, B. abortus, B. suis, B. ovis, B. canis, and B. neotomae suitable for both conventional and real-time PCR systems. J. Microbiol. Meth. 2008, 75, 375-378. [CrossRef] [PubMed]

Sample Availability: Samples of the compounds are available from the authors.

(C) 2016 by the authors; licensee MDPI, Basel, Switzerland. This article is an open access article distributed under the terms and conditions of the Creative Commons Attribution (CC-BY) license (http://creativecommons.org/licenses/by/4.0/). 